\title{
A Pilgrimage Through the Mist of Legends: Reconstructing the Life and Works of 'Abd Al-O_adir Al-Jilani
}

\author{
Achmad Munjid \\ Religious Studies Department, Temple University, Philadelphia- \\ USA. \\ Email:a_munjid@yahoo.comamunjid@temple.edu
}

\begin{abstract}
Western scholars on Sufism so far have paid more attention to Sufi figures that left us with many written works, either in the form of poems, biography, apologia, or mystical treatise. Practically, al-Jilani only left us with three original works, wherein we do not find any 'brilliant theory' about Sufism. So, at the face value, this Western academic indifference about al-Jilani is just plainly plausible. Al-Jilani's marginal position in the Western academic studies on Sufism in fact is an indication of a subtler ideological bias among many scholars. This article examines the life and works of al-Jilani while proposing a new theoretical basis in the study of Sufism. The writer argues that al-Jilani's teaching is popular Sufism by definition

Keywords: al-Jilani, spirituality, popular sufism
\end{abstract}

\section{ABSTRAK}

Khazanah akademis Barat tentang Sufisme memberikan perhatian kepada para tokoh Sufi beserta karya-karya yang mereka tinggalkan, baik dalam bentuk puisi, biografi, apologia maupun risalah-risalah mistik. Sementara itu, al-Jilani sendiri pada kenyataannya hanya meninggalkan tiga buah karya orisinal yang di dalamnya kita mungkin tidak menemukan teori yang brilian tentang Sufisme. Oleh karena itu, studi akademik di Barat tentang Sufisme yang nampaknya mengabaikan al-Jilani dapatlah dipahami. Posisi al-Jilani yang marjinal menunjukan adanya bias ideologis di kalangan para sarjana. Tulisan ini berupaya merekonstruksi kehidupan dan dan karya alJilani sembari menawarkan basis teoretis baru dalam studi Sufisme.

Penulis berpendapat bahwa ajaran-ajaran sufisme dari al-Jilani dapat dikatakan sebagai Sufirme popular.

Kata Kunci: al-Jilani, spiritualitas, sufisme popular

\section{INTRODUCTION}

Since by definition history is always an arena of contestation, a history of great people is an arena of various competing interpretations, imaginations, impositions and interests. Therefore, a history of great personality, in many cases, becomes hagiography. ${ }^{1}$ The story of 'Abd al-Qadir al-Jilani exactly falls in this position. Not only books written by his modern followers like The Saint of Jilan, ${ }^{2}$ even some scientific encyclopedias are tempted to write more about his legends and miracles than alJilani's historical life. ${ }^{3}$ This article seeks to reconstruct the life and works of al-Jilani from the thick haze of legends and hagiographic accounts in order to have a sharper image of him as a historical figure. As point of departure it will address the 'academic reluctance' of Western scholars on Sufism about al-Jilani. Then while 
presenting his life and works this paper will explain why al-Jilani became one of the most celebrated Sufis in the Muslim World. In the end, suggestive points of further research will be given as the conclusion.

Even though 'Abd al-Qadir al-Jilani, with huge number of followers spreading from Africa to Southeast Asia, probably is the most popular saint in the Islamic world, as indicated by Schimmel and others, ${ }^{4}$ surprisingly enough, works about him are fewer than those on other well known Sufis. This academic reluctance, in my opinion, is due in part to al-Jilani's position in Western academic discourse with at least three reasons. First, he is neither a prolific writer nor a great thinker, especially when compared to such figures as Ibn 'Arabi (d. 638/1240), Jalal al-Din Rumi (d. 672/1273) and al-Ghazali (d. 505/1111) who have been exhaustedly studied. Perhaps, in modern terms, al-Jilani is more an activist than an intellectual. Western scholars on Sufism so far have paid more attention to Sufi figures that left us with many written works, either in the form of poems, biography, apologia, or mystical treatise. Practically, al-Jilani only left us with three original works, wherein we do not find any 'brilliant theory' about Sufism. So, at the face value, this Western academic indifference about al-jilani is just plainly plausible.

However, if we pay closer attention to the issue of Western scholars' indifference to alJilani actually is not without theoretical problem. As we know, in many modern academic studies like that of Alfred Bel, Sufism is categorized as a form of popular religion in contrast to an "Arab" Islamic orthodoxy. In Ernest Gellner's terms, Sufism is a form of personalized religion that is ritually indulgent, hierarchical, mediated and lack of Puritanism, in opposition to an egalitarian, immediate and scripturally oriented Islamic orthodoxy. Furthermore, these differences reflect the dichotomy between the rural illiterate society whose religion is more "emotional" in contrast to urban literate society that practices religion in a more rational way. ${ }^{5}$ Some argues that this dichotomy theory, in fact, suffers from Weberian 'Protestant' bias. We will come back to this issue later. Now, paying attention primarily to verbal text (literacy) than to social text (orality) that eventually has led to marginalization of al-Jilani's position, in my opinion, is just a subtler manifestation of this 'protestant' academic bias. ${ }^{6}$ If in anthroposociological reality, al-Jilani is the most celebrated Sufi around the Muslim world, why then his existence is ignored for such a long time only because he left us with fewer literary works? Position and positioning are always connected to relation, perception and interest. Therefore, in itself it is always political.

Second, to follow Selden P. Delany's categorization, ${ }^{7}$ al-Jilani is more a "common" saint, rather than the "heroic" ones like alHallaj (put to death in Baghdad in 309/922), Shihab al-Din al-Suhrawardi al-Maqtul (killed in Aleppo in 465/1191) and 'Ain al-Qudat alHamadhani (killed in Hamadhan in 525/ 1131), the sufi martyrs. ${ }^{8}$ In many respects, alJilani's historical life and works are almost just 'normal', or "sober", to be more precise. With four wives and 49 sons, according to Schimmel, ${ }^{9}$ al-Jilani clearly even was not a pure ascetic, an ideal type of the saint in the (Christian) West. Can one then argues that it is because of this 'normal life' reason as well as his 'effective public service' that made him so widely popular among Muslim societies? In 
the case of his marriage, in addition to merely an indication of 'normal life', it is worth noting here that sanctity in fact is not incompatible with marriage. ${ }^{10}$

Third, not until recently, modern studies on Sufism in the West tend to neglect the organizational aspect, the mystical orders, of Sufism. ${ }^{11}$ "...practically nothing has been said of the major importance of such Sufi revivals as those of Darqawiyyah and Tijaniyyah in North Africa, the Yashrutiyyah in East Africa and the Arab Near East, the

Ni'matullahiyyah in Persia and Southern India and the Chistiyyah and Qadiriyyah Orders in Indo-Pakistani sub-continent," writes Sayyed Hossein Nasr. ${ }^{12}$ While the most phenomenal aspect of al-Jilani is his capability in gaining the huge followers so that Qadiriyyah, his order, is the first tariqa (Sufi order) to take on a distinct character, or simply the first tariqa as such. ${ }^{13}$ Other orders have arisen out of it. ${ }^{14}$

\section{HIS LIFE}

'Abd al-Qadir ibn Abi Salih al-Jilani was born to a Persian family ${ }^{15}$ in 470/1077 in Jilan, which also known as Vailam, in the Northwest of Iran, South of the Caspian Sea, where Hanbalism was strong. Al-jilani was born when Malik Shah the Saljuq (465/1072485/1091) ruled over a vast Muslim Empire and his Islamic Kingdom was famous for great patronage of learning. Unfortunately, soon after the violent death of Malik Shah, fight for succession brought the country into anarchy and disorder. The chaotic situation went on and on, paused for a while, but then became even worse when Sanjar, Malik Shah's later successor who could handle the political turbulence for a while, also untimely died in 552/1157. Constant wars between the
Seljuqs happened everywhere and made the Empire fell into apart. Meanwhile, elsewhere, Crusades broke out, first from 488-9/1095 to $493 / 1099$ and then the second from 540/ 1145 to $544 / 1149 .{ }^{16}$

It is in this critical situation that al-Jilani came to Baghdad in 488/1095 at the age of 18 and pursued a legalistic course of Hanbali training. ${ }^{17}$ Perhaps related to the issue of school (madhhab) affiliation between Nizamiyyah that supported Ash'ariism and the Hanbalite background of al-Jilani, he refused to study at the Nizamiyyah of Ahmad al-Ghazali who had succeeded Imam Abu Hamid al-Ghazali. ${ }^{18}$ Apart from other numerous teachers in various fields of study, he studied philology under al-Tibrizi (d. 502/ 1109), hadith under Abu Muhammad Ja'far alSarraj (d. 500/1106), Hanbalite law under Abu al-Wafa' bin al-'Aqil (d. 513/1119) who had previously converted from the Mu'tazila to Hanbalism, and under the jurist Abu Sa'ad al-Mubarak 'Ali al-Mukharrimi (d. 513/1119), where he got the khirqa, the Sufi robe, given as the sign of the end of a noviciate. ${ }^{19}$ However, there is no evidence that he got any Sufi training until he joined the school of Abu alKhair Hammad al-Dabbas (d. 525/1131), a syrup vendor by trade who was also a highly appreciated Sufi master of his time.

Al-Jilani was over fifty years when he first appeared in public as a preacher in 521/1127, allegedly only after strong endorsement of Yusuf al-Hamadani (d. 534/1140), a very well known Sufi master with the title of Qutb or "Axis of the Age". Before this public appearance and after his graduation from alDabbas's school apparently al-Jilani spent some twenty-five years as a wandering ascetic in the desert of Irak. ${ }^{20}$ Continuously lived in severe self-discipline, he would often stay up 
whole night in worship and/or reading the Qur'an from beginning to end (a common exercise among the very pious Muslims). $\mathrm{He}$ wandered and took a long course, first at a town in Khuzistan (in the lower

Mesopotamian plain) and then back to Baghdad. ${ }^{21}$

From the aforementioned 'first public sermon' day on his reputation grew up very quickly as a famous Hanbali preacher and great teacher of courses on religious instructions. In the meantime, he also got married. If for a quite long time he regarded marriage, or perhaps sex, as a hindrance in his spiritual quest, now he treated it as social duty where the Prophet himself has already given the example. He married four women from whom he got twenty-seven sons and twentytwo daughters in the long course of his life. ${ }^{22}$ Four of his sons became well known as religious scholars like himself. Despite his public life, he continued his personal austere life, like fasting all year around, except for the forbidden days to do so. ${ }^{23}$ Many scholars agree that historically al-Jilani is a personage who possessed a very striking piety, hospitality and philanthropy.

Thanks to his vast and deep knowledge, as well as that humility, powerful sincerity and charming personality, his teaching and particularly his public sermon became extraordinarily popular in Baghdad area. In $528 / 1134$ he was installed as the head of the school used to be under his old teacher, alMukharrimi. A complex of much larger school and residence for him, his large family and his pupils were built in with financial aid from the rich and free labor from the poor. Due to the rapid increasing numbers of his audience, not only his college was re-enlarged, his regular preaching (on Wednesday and
Friday morning) should also be held in a larger prayer ground outside the city, for there was no other place large enough to accommodate the crowds. Therefore, a ribat was built for him. ${ }^{24} \mathrm{~A}$ legend says that at times about seventy thousands people attended his sermon and everyone in the farthest distance could hear al-Jilani's voice as clear as those gathered close to him. ${ }^{25}$ Visitors of Baghdad would not miss his speech. After $d z u h r$ prayer al-Jilani gave out edicts on shari'a and ethic to meet the requests of people, sometimes sent from distant lands. ${ }^{26}$

Contrary to the general assumption of his contemporary followers, according to various sources, during his lifetime al-Jilani never claimed himself as a Sufi master. Fazlur Rahman argues that it is highly improbable that al-Jilani intentionally established an order besides training his immediate circles of spiritual disciples. ${ }^{27}$ In agreement with him, Trimingham says that Al-Jilani did not leave any system, let alone Path or Way to be followed. ${ }^{28}$ For Margoliouth, even claim that al-Jilani's sons propagated his Way in the Muslim world, as proposed by many scholars, is also problematic. ${ }^{29}$ During his lifetime, alJilani dressed like an 'alim, religious scholar, and well known more as a Hanbali preacher, rather than a Sufi. ${ }^{30}$

In fact, al-Jilani was active as mufti, teacher of Qur'anic exegesis, hadith and figh classes that were held in daily basis, and especially as prominent public preacher that attracted numerous pupils from all over the Muslim world. His persuasive discourses are said to have made many Jews and Christians converted to Islam and won many Muslim sinners to repentance. With his principle teaching and wide popularity, his position reached independence so that he could freely 
criticize the caliph. In an era like his where worldliness and power became mainstream ideology of the people and even ulama (religious scholar) were part of the state's political apparatus, criticizing caliph was almost a 'mission impossible'. Stories around him recorded that al-Jilani was always happy to leave his works in order to help children, a destitute or a slave, but never wanted to stand up in the honor of any person of high rank. If he got information that the caliph would be visiting him, he deliberately went inside his house so that he did not need to stand up to welcome him. He passed away in his ripe age of 90 in 561/1166. Until today his tomb in Baghdad, over which Sultan Sulayman (r. 1520-1566) built a very beautiful turba in $941 / 1535$, become one of the most revered and frequently visited sacred sites of pilgrimage by Muslims all over the world.

In relation to his era, to follow Braune, it is worth noting that al-Jilani lived in the time where socio-religiously people were divided between secularism or religious indifference and conventionalism, on the one hand, and religious intellectualism and doctrinism, on the other hand. People were entrapped either by the vanity of the world or the emptiness of the legalistic religion. In part, it is al-Jilani's breakthrough in giving the "dead body" of legalistic Islam with the spirit and emotional aspect of Sufism that made his movement rapidly widespread. It is clear from his historical life and works that he adopted a very sober Sufism. Conflicts between Sufism and Shari'a, as frequently found in many of his contemporaries, do not occur in his writings. In al-Jilani's teaching, ecstatic practices, though not forbidden, are allowed only within certain restrictions. Ascetism should not violate the duties towards family and society. A saint, even when he reaches the highest spiritual experience, can never achieve the rank of the prophets, let alone going beyond it, as found in some teaching of other Sufis. ${ }^{31}$ The way many of his followers treated him sometime more than the prophet himself, of course, is an irony.

In relation to the issue of Western scholars' reluctance to study al-Jilani, this issue of al-Jilani's wide popularity and his sober Sufism is particularly interesting. While academic 'protestant' prejudice assumes that Sufism is a form of popular religion in opposition to the 'Arab' Islamic orthodoxy, al-Jilani appears to be an anomaly in that perspective. His background is Hanbalite, a school very well known for its legal rigorism. If legal rigorism and mysticism are supposed to be mutually exclusive in Islam, again, why alJilani, a Hanbalite prominent preacher and acted primarily as such during his lifetime then became the most celebrated saint in the Muslim world? If the dichotomy is accepted, there is simply no bridge to unite both sides under the phenomenon of al-Jilani. Even if one can propose a theory that a saint is a saint because others treat him/her as such, it still cannot sufficiently explain the subsequent question: given the fact that he did not inherit his popularity from his parent, then why so many people, in the wide spectrum of time, places and cultures, treated al-Jilani so? In this regard, both Montgomery Watt's claims that al-Jilani, being a Sufi, could no longer belong to Hanbali School and that his affiliation to Sufism was influenced by alGhazzali are in contradiction to many historical data. ${ }^{32}$

Meanwhile, to draw attention more to his followers' psychology than to the actual 'power' of al-Jilani, as proposed by Hodgson, 
perhaps can say something as 'after-the-fact' explanation of his popularity. So it makes some senses to say, "what came to matter was the authority of the founding figure rather than his insight". ${ }^{33}$ But, it says nothing about how the authority itself was originally established and why the institutionalization of the original charismatic leadership was possible. Was it more about the mental creativity of alJilani's followers in producing a myth about him rather than his actual greatness? Is alJilani just 'nothing' despite many of his followers unconsciously treated him as even more than Muhammad himself as a religious personality? ${ }^{34}$ Or was it a merely historical incidence? The further the dichotomy theory of Sufism versus orthodoxy goes, for me, the clearer becomes its hidden message. That is, assumption that either Sufism is not an integral part of Islam or that Islam, by definition, is a rigid legalistic religion. More than just not properly explained, the case of alJilani, I think, is an example of the annulment of that theory.

In that regard, I tend to read the phenomenon of al-Jilani from different angle. As suggested by Schimmel ${ }^{35}$, perhaps it was precisely the strict adherence to the outward letter of the God-given law and the deep respect for the divine word that enable alJilani and others to reach a deeper understanding of the secret of the revelation and to spread it among the people in a very sober way. Therefore, with his strong form and deep content of his teaching, and above all the way he consistently practiced them, alJilani became the most widely accepted Sufi figure in the Muslim world. Of course, general factors, including mainly the 'protest function' one, influencing the overwhelming attraction of Sufism among the common people, as suggested by Fazlur Rahman, should be seriously taken into account at this point. $^{36}$

Meanwhile, every modern writer has always been complaining about the difficulty to penetrate the layers of legends that were established even during al-Jilani's lifetime and then thickened soon after the death of this sultan al-awliya (the King of Saints). Bahjat alAsrar, the first most elaborate biography of alJilani by Ali ibn Yusuf al-Shattanawfi (d.713/ 1314) and written over a century after the death of this al-Muhyidin (the Reviver of Religion) is referred by many modern scholars as the book responsible for the complete obscurity of al-Jilani's personality. ${ }^{37}$ Omitting al-Jilani's practical works and teaching, this book is just bubbling imagination and fantasy in which common people could take refuge from daily life depression and to get consolation. ${ }^{38}$ In this book, al-Jilani is not described according to an ideal of the saint conceived even by al-Jilani himself. Al-Shattanawfi's presentation of al-Jilani is so perfect that it is impossible to any human being to achieve his position. Instead of a description of an ideal human being, this book presents al-Jilani's power as the manifestation of the inconceivable and incomprehensible of God Himself. Therefore, here, nothing is impossible for alJilani.

"My foot is on the neck of every saint of God" is probably the most popular words attributed to al-Jilani by which he got the title of "the King of saints". From his infancythus the legends go-al-Jilani did not want to suck his mother's breast during the Ramadan, the fasting month of Islam. He punished the sinners and helped the oppressed by just saying some words or moving a gesture from a distance. He walked upon water and moved 
through air. Angels and jin (the unseen people) and even Muhammad himself appeared at his meeting and gave him appreciation. ${ }^{39}$ Or, he could just literally wash away the text of a philosophy book he considered to be dangerous to his disciples. ${ }^{40}$ Animals, plants and stones would obey him. Even the month will present itself to him as either a beautiful or ugly youth, according to the events that were to take place in the coming four weeks. ${ }^{41}$ In a poem, al-Qasida al-Ghawtiya, he is described as having power to extinguish fire, raise the dead, crush mountains, dry up seas, etc. ${ }^{42}$ In Indonesia, hundreds of thousands of his contemporary followers believe that al-Jilani even visited and played a significant role in the Islamization of the Archipelago. ${ }^{43}$

It is highly possible therefore that a modern writer like S.A. Salik gained his legends and miraculous stories about al-Jilan mainly from al-Shattanawfi and the similar authors. In addition to some of the aforementioned legends, The Saint of Jilan presents so many other wonderful stories about al-Jilani. For example, everything about his name, place of birth, religious characteristics and the "My foot is on the neck of every saint of God (wali)" statement is predicted by some saints long before al-Jilani was born. Among the most quoted stories about al-Jilani is his honesty and the repentance of robbers. When he left for Baghdad to get further religious training, his mother gave him 40 dinars (gold coins) by sewing them into his garment so that they might not be easily stolen or lost. It was a half of the whole inheritance left by al-Jilani's father. "Don't tell any lie whatsoever," his mother said and he agreed. On the way to Baghdad a group of robbers seized the caravan where he was in, but never touched him, regarding al-Jilani as the penniless young man. One of the robbers then asked him if he had anything. "I have 40 dinars, sewed into my garment," al-Jilani said. No body believed him until the leader of the gang came and finally proved it by cutting open al-Jilani's garment. "Why did you tell it?," the leader of the robbers asked in astonishment. Al-Jilani told him about his promise to his mother. Upon this the leader of the robbers burst into tears and said he had been breaking the commands of God throughout his life and thus made repentance. ${ }^{44}$

In other part, al Jilani is described as practicing extreme severe self-discipline so that he lived in the ruins of Madain where for a year he only ate vegetables but not drinking any water. In the next year he drank water only, without eating anything. In the third year he neither ate nor drank, nor slept. ${ }^{45}$ Another popular story is related to his title of "Muhiyuddin" (the reviver of religion). On a Friday in 511 al-Jilani was coming barefoot to Baghdad. On his way, he found a very sick man who asked his help. As soon as al-Jilani helped him, this man suddenly began to grow big in stature. When al-Jilani was a little bit frightened, the man said that he himself is the religion of Islam. Allegedly Islam had grown weak with the time, but now was restored to health by al-Jilani. Since then al-Jilani got his title as the reviver of religion. ${ }^{46}$ Other al-Jilani's biographical book contains stories like the Prophet Muhammad spit on his mouth-as a sign of approval for alJilani to be his spokesman, his conversation with the serpents and that he was accompanied by al-Khidr when first came to Baghdad etc. $^{47}$

For me, those legends, while they cannot be accepted as empirical or historical data 
about the life of al-Jilani, they are interesting as social text to 'read' the life of this great saint. Clearly, again, there is a dark area between al-Jilani's modesty both in his writings and as a 'humble hero' in his life, on the one side, and his huge popularity as a Sufi figure throughout the Muslim world, on the other side. It seems that both al-Jilani's blind followers and many Western scholars have a similar problem in understanding this issue but come out with two opposite answers. On the one hand, being incapable of explaining that dark area many Western scholars escape from the problem by ignoring al-Jilani's existence and indirectly assume that he is just a product of 'irrational' popular religion of the oral society. On the other hand, incapability of al-Jilani's followers in understanding the same issue is reflected in the indulgence of over idealized imagination in making him as super hero. Anything perfect is attributed to al-Jilani so that from time to time al-Jilani's figure is being perfected in accordance with popular mind.

For me, as a social text, this legend is just like the shadow of a concrete figure. It is not real, but also cannot be rejected right away as just useless. At least the hidden logics of those legends reflect both the power of al-Jilani's teaching and the 'originality' of his movement on the one hand and the 'dream' of the people about their ideal hero, on the other hand. Therefore, only when we read the language of those 'mythic' stories and books on al-Jilani more as a language of metaphor then we will get something from the story. How this should be implemented and what the possible results are topics for further research beyond the scope of this paper. For now, it is sufficient to say that the way al-Jilani's followers described him is a 'type of speech'48 with its own logic in expressing what is linguistically "inexpressible", the sacred. For them, al-Jilani as part of the sacred that can never be described adequately by language and thus it needs allegory and metaphor. The illustration and symbol in the story, therefore, is more connotative than denotative.

As a mythical (as well as mystic) figure, alJilani can walk upon water, move on air and even come to different era to teach people who live two, three, or some centuries after his death. Theoretically, his presence and existence among the followers here should not be imagined as empirical or historical, but "metaphorical" 49 . Sociologically, his followers use him not anymore as an integral part of their reality by which they perhaps can solve their actual problem. They use him rather as inspiration either to understand or to explain reality. Al-Jilani's words, or words attributed to him, thus are taken as part of performative sources rather than the informative ones. Just like when we read the story of Mahabharata, the actuality and factuality are not important. What do matter are the 'logics' and the meaning of the story. My assumption here, of course, is that al-Jilani's followers are practicing this "metaphor model" without necessarily being aware of doing it. It is just like every speaker of any particular language who uses the language without never consciously being aware of using its grammatical structure. To have a fuller discussion about al-Jilani now let us turn to his works.

\section{AL-JILANI'S WORIKS}

According to some scholars, among alJilani's few works, Futuh al-Ghaib (Revelations of the Unseen) is the most important and 
famous one. ${ }^{50}$ This collection of al-Jilani's eighty discourses, compiled by his second son, 'Isa (d. 573/1179), ${ }^{51}$ reflects both al-Jilani's main messages and the socio-historical situation of his time. Here, we can find how alJilani presents his spiritual teaching in such a form as to illuminate the everyday moral problems of his society. Ibn Taymiyah (d. 728/1328), himself 'notorious' as a bitter opponent of Sufism according to some scholars, wrote a long respectful commentary on Futuh al-Ghaib and call al-Jilani as "our teacher". ${ }^{2}$ George Makdisi goes even further by claiming that Ibn Taymiyah was a member of Qadiriyyah order. ${ }^{53}$

As frequently repeated in his other sermons, in this book al-Jilani states that social ruins and instability are product of excessive materialistic perspective on life and that the true well being results only from a harmonious development of personality whose inner and external or physical and spiritual needs are well taken care of. The chief underlying traits of al-Jilani's teaching are, in fact, the dissuasion from being immersed in worldliness and emphasis on charity and humanitarianism. "To close the gates of Hell and open the portals of Paradise for all mankind" is among his well-known mystical statements, ${ }^{54}$

As a response against indulgent materialism-or worldliness in general, including the use of religion by many religious scholars to gain short-term political and other profane interests-in his era, al-Jilani's sermon in Futuh al-Ghaib frequently emphasizes the necessity of strict sincerity (ihlas). In Discourse 54, for example, al-Jilani suggests people to adopt even a complete or total indifference to the world, to 'clean up' any kind of ambition and desire from his/her heart. Against the context of his time, certainly, this is a 'reverse logics' for the people. A reversion needed as a shock therapy in order to make people aware of their real meaning of life. Let me make a rather long quotation on this issue:

"So as long as any desire from among the desires of this world continues to exist in his heart and any relish from among the relishes of it and any effort for comfort from among the comforts of it in regard to various things of food and drink and dress and marriage and residence and conveyance and rulership and chieftainship and the advancement in his knowledge of various branches of learning and of jurisprudence in preference to five institutions of worship and to the narration of hadith and the recitation of the Qur'an with its varied readings and syntax and lexicography and rhetoric, as also the desire for the disappearance of poverty and appearance of affluence and the departure of calamity and the coming of comfort and in everything the removal of difficulty and coming of benefit-if such desire lingers in the mind of a person he is certainly not a pious man.... Next he should be indifferent towards the life hereafter so as not to wish for ranks and high grades and beautiful maidens and handsome boys and houses and mansions and conveyance and suits of clothes and ornaments and articles of foods and drink and other things of this kind from among what God, the Great, has kept prepared for His believing servants." 55

This topic of pacifism towards everything, then leads us to al-Jilani's understanding of free will and determination of human being. In his earlier discourse, al-Jilani positioned himself in between the Jabariyya (the Fatalists) and the Qadariyya (the Indeterminist group) and said "You should rather say that actions 
belong to God in point of creation, and to men in point of effort (kasb)" ${ }^{26}$. In his later discourses, however, al-Jilani tends to move closer to the position of Jabariyya group. In the Discourse thirteenth he said: "Do not make any effort to appropriate any blessing, nor to ward off any calamity. The blessing will come to you if it is destined for you, whether you seek it or dislike it. And the calamity will overtake you if it is destined for you, whether you dislike it or try to ward it off by prayer or confront it with your patience and fortitude in order to earn the pleasure of the Lord. ${ }^{57}$ " In another discourse he even says "Regard good and evil as two fruits coming out from two branches of the same tree." ${ }^{58}$ Here and again, al-Jilani speaks about the necessity of total annihilation of the will and complete surrender to the predetermined decree of God. Not surprisingly, Ibn Taymiyya, an "activist" and the vanguard proponent of the primary of shari'a as well as the admirer of al-Jilani, is at pains to interpret al-Jilani's position here. For Ibn Taymiyya, al-Jilani's total annihilation means giving up from the permitted things which are not commanded, for there maybe some dangers in them. This is just an application of the notion of ijtihad into the spiritual path. In his effort to unite his will with God's will, the true Sufi arrives at a condition where he desires nothing other than to discover the greater good, the action which is most pleasing and lovable to God. While, this is Ibn Taymiyya's 'brilliant invention' in itself, according to Thomas Michel, in fact Ibn Taymiyya and al-Jilani are not speaking of the same reality. Rather than an interpretation, Ibn Taymiyya's idea is therefore more a revision, if not a refutation. ${ }^{59}$

Meanwhile, according to al-Jilani, there are four categories of people. First, people with no heart and tongue, namely those who never care about truth and virtue and are always indulgent themselves with their senses. Second, people who have tongue, but no heart. This is an allusion to the ulama who just sell out their knowledge for worldly matters, the dangerous 'evil learned man'. People should keep away from both of those groups. Third, people who have heart but no tongue, friends of God in His secret. Fourth, people with heart and tongue, namely people with deep knowledge of God who have capability and will in expanding it to human being. This is the end and culminating point of mankind and there is no station above this, excepting that of prophethood. ${ }^{60}$

Now, let us turn into the topic of mystical union with God, the most complicated and controversial issue in any school of mysticism. According to al-Jilani, the term union should be understood primarily as symbolical. "The meaning of union with God is your going out of the creation and desire and purpose and becoming established in His action and His purpose without there being any movement in you or through you in His creation unless it be with His order and action and command. So this is the state of fana by which is meant union with God." ${ }^{11}$ With regard to this understanding, it is not surprising that Ibn Taymiyyah, among the strongest opponents of Unity of Being 'theory' in Sufism can accept alJilani's teaching. Since, here what al-Jilani means by union is more a union of the "will".

In other part of his works, al-Jilani also made a list of ten virtues, that, thank to which and if well-rooted into practice, will lead to full spirituality. First, not to swear by Allah, either truthfully or falsely. This is somewhat strange, since swearing by Allah seems to have been 
part of almost every Muslim's daily life.

Second, not to speak any untruth, even in jest. Third, not to break a promise. Fourth, not to curse or harm anything. Fifth, not to pray or wish for harm to anyone. Sixth, not to accuse anyone of religious infidelity. Seventh, not to attend to anything sinful. Eighth, not to impose any burden on others. Ninth, not to expect anything from human beings. And the last one, to notice only the points in others that may be superior to oneself ${ }^{62}$. Indeed, those principles are easily understood by everyone, unlike some teachings of many other Sufis.

His other works are al-Fath al-Rabbani (The Sublime Revelation) consists of sixty-two sermons delivered in 545-6/1151-6. Both here and in Futuh al-Ghayb, al-Jilani frequently speaks of the "perfect saint". But, again, as always, he speaks of it not in technical terms of the Sufis. As we know, in Sufi literature, there is an understanding that if the cosmic purposiveness were to be complete, then there must be the 'perfect man' somewhere in the universe, in whom this cosmically culminative human role should be brought into perfection. There must be someone who knows all thing and above all knows about Allah completely. This perfect man is known as the qutb (the axis of the age). ${ }^{63}$ Al-Jilani's simplicity presumably reflects that the address of his sermons, the audience, was "common people". He spoke not to 'a happy few' group about very special thing in a technically sophisticated way. Instead, he spoke to the people in general about their shared problems and the possible solution.

According to him, a perfect saint as the ideal figure of man is the one who has overcome his accidental self and reached the essential being, conquering the fear of fate and death, since this saint has enjoyed his participation in Him who creates the fate and death. For al-Jilani, this is the real meaning of (great) jihad, a war against one's self-will. This is a 'war' against shirk, the idolatry of the self. Polytheism, for him, consists not merely in idol worship. "It is also polytheism to follow the desire of the flesh and to adopt anything of this world and of the hereafter in association with God." 64

His al-Ghunya li-Talibi Tarik al-Haq (Sufficiency for the Seekers of Truth) is more a doctrine on theology. ${ }^{65}$ In this book al-Jilani elaborates his exposition of ethical and social duties of a Sunni Muslim. It also lists the knowledge required for a believer, including a brief understanding of the seventy-three sects of religion and ends with an exposition of particular Sufism. ${ }^{66}$

There are other books, attributed to alJilani, but either in term of style or content or both are not reliable as al-Jilani's original works. Among them are Malfuzat (Utterance of Shaik 'Abd al-Qadir al-Jilani), ${ }^{67}$ a collection of various sayings of al-Jilani, generally to be found as an appendix to the Arabic edition of Fath al-Rabbani. Khamsata 'Ashara Maktuban (Fifteen Letters) is a collection of letters allegedly written by al-Jilani at the request of one of his disciples, while Jala' a- Khawatir (The Removal of Cares) is a collection of other forty-five discourses of al-Jilani. Another book entitled Sirr al-Asrar (The Secret of Secrets), is very interesting. It consists of alJilani's explanation about things from the beginning of creation, the division of human beings, namely, the saints and those who posses charismatic talent; the division of sciences into shari'a (sacred law), tariqa (spiritual path), ma'rifa (direct knowledge) and 
haqiqa (reality), practice of remembrance (dzikr) until a detailed manual of litany (awrad). However, those books are full of historical anachronisms.

To go back to the issue of al-Jilani's teachings as recorded in his original books, I do not agree with Trimingham who argues that al-Jilani's reputation was certainly not gained from the content of his sermons. ${ }^{68}$ That statement is perhaps applicable to al-Jilani's position among the Western scholars, but not in the Muslim world in general. On the contrary, it is his capability of not being "too sophisticated" in elaborating the teaching of Sufism that made him more popular than the others-and above all, the singularity between his statement and action, his example in practicing the teaching into real life. This is in accordance with his belief that the ideal type of a mystic is not the one who become recluse or anchorite, but a man of the world whose life and words become the examples that help the ignorant and misguided to the way of righteousness. ${ }^{69}$ For alJilani, "tasawwuf is gained not through discussion and talk or intellectual exercise, but through hunger and giving up of things like and approved of." ${ }^{70}$ His Sufism is based on eight qualities: a) generosity (like that of Ibrahim); b) cheerful submission (like that of Ishak); c) patience (like that of Ya'cub); d) prayer (like that of Zakaria); e) poverty (like that of John the Baptist); f) life modesty (like that of Moses); g) traveling about (like that of Jesus) and h) religious poverty (like that of Muhammad). ${ }^{71}$

Being a Sufi, for al-Jilani, is not basically being alone except only with

God, as reflected by the first stage of his mystical quest, but being with "others" always in God.

\section{CONCLUSION}

Finally, let me now conclude this simple paper with some important points. First, alJilani's marginal position in the Western academic studies on Sufism in fact is an indication of a subtler ideological bias among many scholars. Therefore, deeper and wider research on al-Jilani is a challenging project both to provide with a sharper history of alJilani, and thus also shed some more light on Islamic mysticism in general, and to the theoretical paradigm being used to frame alJilani in the Western scholarship. Second, from the above discussion, I argue that alJilani's popularity in the Muslim world resulted from a complex combination of such factors as socio-political history of al-Jilani's era, his sober and 'simple' teaching of Sufism that were presented in the common language for 'everyone', and al-Jilani's very powerful religious personality. In other words, alJilani's teaching is popular Sufism by definition. Third, instead of rejecting those so many legends and myths around al-Jilani, careful researches need to be done about them not only to primarily screen out the fact from the legends or the reality from the myths, but also to read the 'hidden structure' of the story. In this case, modern linguistics and semiotics theories will contribute some important aspects to the study.

\section{ENDNOTES}

\footnotetext{
Of course, with regard to the notion of "subjectivity" in narratives and the role of author in writing, such as proposed by many modern semiotician like Roland Barthes, to immediately put history, or historiography, in a diametrically opposed position with hagiography is not unproblematic. However, in this short article I will use the distinction to identify which one is more reliable than the others in a more conservative understanding of history. For a more detailed discussion about the problem of historiography versus hagiography see, for example, Thomas J. Heffernan,
} 
Sacred Biography. Saints and Their Biographers in the Middle Ages (Oxford: Oxford University Press, 1988), pp. 38-71.

2 Saiyed Abdus Salik, The Saint of Jilan. Ghaus-ul-Azam (Lahore: Ashraf Publication, n.d.). In his preface, the author claims that that very small book is the first English publication on al-Jilani's biography.

3 See Cyril Glasse, The Concise Encyclopedia of Islam (London: Stacey International Publisher, 1989) p. 15.

4 See Annemarie Schimmel, Mystical Dimensions of Islam (Chapel Hill: The University of North Carolina Press, 1975), p. 247; Glasse, The Concise Encyclopedia of Islam, p. 15; and also Martin Lings, What is Sufism? (London: Mandala Books Unwin Paperbacks, 1981), p. 112.

5 Ernest Gellner, Saints of the Atlas (Chicago: University of Chicago Press, 1969), pp. 7-8.

6 For a suggestive discussion about a similar issue, see, for example, Vincent J. Cornell, Realm of the Saint. Power and Authority in Moroccan Sufism (Austin: University of Texas Press, 1998), pp. xxv-xxxiii.

7 Selden P. Delany, Married Saints (Freeport, NY: Books for Libraries Press, 1969), p. v.

8 A.J. Arberry (trans.), A Sufi Martyr. The Apologia of 'Ain al-Qudat al-Hamadhani (London: George Allen and Unwin Ltd., 1969), p. 9.

9 Schimmel, Mystical Dimensions of Islam, p. 248.

10 It is interesting to note that even in Catholicism where celibacy is celebrated, history of many saints also proves that sanctity and marriage do not have to be incompatible. Delany's above mentioned book is an interesting account on this issue.

11 J. Spencer Trimingham, The Sufi Orders in Islam (Oxford: Oxford University Press, 1971), p. v.

12 Sayyed Hossein Nasr, Sufi Essays (Albany: SUNY Press, 1991), pp. 12-13.

13 Glasse, The Concise Encyclopedia of Islam, p. 16. There are disagreements among scholars whether Oadiriyyah is the most widespread tariqa in the Muslim world. Some claims so, like Marshall G.S. Hodgson, The Venture of Islam. Conscience and History in a World Civilization, Vol. 2 (Chicago: The University of Chicago Press, 1974), p. 216. On the contrary, other says that Qadiriyah never became popular; see Trimingham, The Sufi Orders in Islam, p. 43. Nevertheless, generally speaking, they agree that al-Jilani is the most universally popular saint.

14 Canon Sell, The Religious Orders of Islam (Wilmington: Scholarly Resources, Inc., 1976) pp. 38. This book represents an early preliminary note on Sufi orders, especially within African context.

15 The Persian name of his father asserts this claim. At the same time, it also contradicts the claim of many that he was descended in paternal and maternal lines directly from al-Hasan and al-Hussein, the grandsons of the
Prophet Muhammad. Read H.A.R. Gibb et.al. The Encyclopedia of Islam, Vol 1 (London: Luzac \& Co, 1960), p. 69.

16 On a brief history of the crusades, read Hans Eberhard Mayer, The Crusades (Oxford: Oxford University Press, 1988).

17 Mian Mohammad Sharif, A History of Muslim Philosophy, Volume 3 (Wiesbaden: Harrassowitz, 1963) p. 349.

18 This very year of al-Jilani's arrival in Baghdad is the crisis year of al-Ghazali after the assassination of his mentor, Nizam al-Mulk. Read W. Montgomery Watt, Muslim Intellectual. A Study of al-Ghazali (Edinburgh: Edinburgh University Press, 1971), p. 133. About the Ash'ari background of Nizamiyyah College and Nizam al-Mulk and several tensions and riots by the Hanbalite during that time, read Ibid, p. 107.

19 Read entry on "al-Jilani" by W. Braune in H.A.R. Gibb et.al. The Encyclopedia of Islam, p. 69.

20 Tirmingham, The Sufi Orders in Islam, p. 42.

21 Hodgson, The Venture of Islam, p. 208.

22 'Abd' al-Oadir al-Jilani, Futuh al-Ghaib (Lahore: Sh. Muhammad Ashraf, n.d.), pp. 10-11.

23 Hodgson, The Venture of Islam, p. 208.

24 Fazlur Rahman, Islam (Chicago: University of Chicago Press, 1979), p. 158.

25 S.A. Salik, The Saint of Jilan, pp. 34-35.

26 Hodgson, The Venture of Islam, p. 208.

27 Rahman, Islam, p. 159.

28 Trimingham, The Sufi Orders in Islam, p. 43.

29 Margoliouth, Encyclopedia of Islam, p. 609

30 Trimingham, The Sufi Orders in Islam, p. 42.

31 H.A.R. Gibb et.al, The Encyclopedia of Islam, p. 69.

32 W. Montgomery Watt, Islam and the Integration of Society (London: Routledge and Kegan Paul, 1961), p. 246.

33 Hodgson, The Venture of Islam, p. 217.

34 Cf. Rahman, Islam, p.158.

35 Schimmel, Mystical Dimensions of Islam, p. 89.

36 Rahman, Islam, pp. 150-151.

37 Therefore, even among his contemporary like Taqi addin 'Abd Rahman al-Wasiti (d.1343), al-Shattanawfi was accused as kadhab muttahim (an indicted lier). Read a detailed note on this issue in J. Spencer Tirmingham, The Sufi Orders in Islam, pp. 40-41.

38 Cf. Hodgson, The Venture of Islam, p. 217.

39 W. Braune, "al-Jilani", p. 70.

40 Schimmel, Mystical Dimensions of Islam, p. 18.

41 Schimmel, Mystical Dimensions of Islam, p. 208

42 W. Braune, "al-Jilani", p. 70.

43 Read Martin van Bruinessen, "Shaykh `Abd al-Oadir alJilani and the Oadiriyya in Indonesia", Journal of the History of Sufism, vol. 1-2 (2000), 361-395.

44 S.A. Salik, The Saint of Jilan, pp. 8-11. I paraphrase the story into my own words. In other version, the number of the gold coins is 80 . See, for example, Hodgson, The 
Venture of Islam, p. 208. I intentionally quoted some stories of the book to provide with typical illustration of so many legends around al-Jilani.

45 S.A. Salik, The Saint of Jilan, p. 22.

46 S.A. Salik, The Saint of Jilan, p. 27.

47 Muhammad ibn Yahya al-Tadifi (translated into English by Muhtar Holland), Necklaces of Gems, (Hollywood, Florida: Al-Baz Publishing, Inc., 1998).

48 Read Roland Barthes, Mythologies (London: Granada, 1983), pp.114-5.

49 Clearly, this is not to say that al-Jilani is not a historical figure. Remember how the historical Malcom $X$ then are so popular among young Afro-American as an icon of 'rebellion' mainly after Spike Lee's movie. The historical Malcom $X$ and his real life, Denzel Washington's acting in the movie and so many fictional story modifications made by Spike Lee are now so overlapped among the Afro-American youth's popular mind as part of their popular culture. Of course, Malcom $X$ is historical, but now his presence and existence is more metaphorical for those young people. It is not really 'important' which one is historical Malcom X, which one is Denzel Washington dressed as Malcom, or which one is fictional. All of them become part of an effective 'metaphor' to comprehend their reality. And Malcom lived only less than half century ago.

50 Read Glasse, The Concise Encyclopedia of Islam, p. 16; Trimingham, The Sufi Orders in Islam, p.41 and M.M. Sharif, Sharif, A History of Muslim Philosophy, p. 350.

51 To be more precise, 78 sermons are compiled by Isa, plus 2 sermons by 'Abd al-Wahab, al-Jilani's first son. See 'Abd al-Qadir al-Jilani (translated into English by Aftab-ud-Din Ahmad), Futuh al-Ghaib. The Revelations of the Unseen (Lahore: SH. Muhammad Ashraf, n.d.), p. 11. Other writer, however, attributes the compilation to 'Abd al-Razzaq (d. 603/1209), al-Jilani's third son. See D.S. Margolioth, "'Abd al-Kadir al-Djili" in Shorter Encyclopaeda of Islam (London: Luzac, 1961), p. 6.

52 About Ibn Taimiyya's commentary on Futuh al-Ghaib, read Thomas Michel, "Ibn Taymiyya's Sharh on the Futuh al-Ghayb of 'Abd al-Oadir al-Jilani" in Hamdard Islamicus, Vol IV No. 2, Summer 1981, pp. 3-12.

53 George Makdisi, "Ibn Taimiya: A Sufi of the Qadiriya Order" in The American Journal of Arabic Studies, Volume 1 (Leiden: E.J. Brill, 1973), pp. 118-129. Rahman, Islam, p. 158.

55 Al-Jilani, Futuh al-Ghaib, pp. 151-153.

56 Al-Jilani, Futuh al-Ghaib, p. 42.

57 Al-Jilani, Futuh al-Ghaib, pp. 47-48.

58 Al-Jilani, Futuh al-Ghaib, p. 86.

59 Thomas Michel, "Ibn Taymiyya's Sharh," pp. 6-8.

60 Al-Jilani, Futuh al-Ghaib, pp. 100-103.

61 Al-Jilani, Futuh al-Ghaib, p. 59.

62 Hodgson, The Venture of Islam, p. 209.

63 Al-Jilani, Futuh al-Ghaib, p. 227.
64 Al-Jilani, Futuh al-Ghaib, p. 31.

65 According to Fazlur Rahman, this is the most famous work of al-Jilani. See Rahman, Islam, p. 158.

66 W. Braune, "al-Jilani", p. 69.

67 Muhtar Holland (trans.), Utterances of Shaikh 'Abd alQadir al-Jilani (Malfuzat),

68 Trimingham, The Sufi Orders in Islam, p. 41

69 M.M. Sharif, Sharif, A History of Muslim Philosophy, p. 352

70 Al-Jilani, Futuh al-Ghaib, p. 199.

71 Al-Jilani, Futuh al-Ghaib, p. 200.

\section{BIBLIOGRAPHY}

al-Jilani, 'Abd al-Oadir (translated into English by Aftab-udDin Ahmad), Futuh al-Ghaib. The Revelations of the Unseen. Lahore: SH. Muhammad Ashraf.

al-Tadifi, Muhammad ibn Yahya. 1998. (translated into English by Muhtar Holland), Necklaces of Gems, Hollywood, FL: Al-Baz Publishing, Inc.

Arberry, A.J. (trans.). 1969. A Sufi Martyr. The Apologia of 'Ain al-Qudat al-Hamadhani London: George Allen and Unwin Ltd.

Barthes, Roland. 1983.Mythologies. London: Granada.

Bruinessen, Martin van. 2000. "Shaykh `Abd al-Oadir alJilani and the Qadiriyya in Indonesia", Journal of the History of Sufism, vol. 1-2.

Cornell, Vincent J. 1998. Realm of the Saint. Power and Authority in Moroccan Sufism Austin: University of Texas Press.

Delany, Selden P. 1969. Married Saints. Freeport, NY: Books for Libraries Press.

Gellner, Ernest. 1969. Saints of the Atlas. Chicago: University of Chicago Press.

Gibb, H.A.R. et.al. 1960. The Encyclopedia of Islam, Vol 1. London: Luzac \& Co.

Glasse, Cyril. 1989. The Concise Encyclopedia of Islam (London: Stacey International Publisher.

Heffernan, Thomas J. 1988. Sacred Biography. Saints and Their Biographers in the Middle Ages. Oxford: Oxford University Press.

Hodgson, Marshall G.S. 1974. The Venture of Islam. Conscience and History in a World Civilization, Vol. 2. Chicago: The University of Chicago Press.

Holland, Muhtar (trans.). Utterances of Shaikh 'Abd al-Qadir al-Jilani (Malfuzat). no name of publisher.

Lings, Martin. 1981. What is Sufism? London: Mandala Books Unwin Paperbacks.

Margoliouth, D.S. "'Abd al-Kadir al-Djili" in Shorter Encyclopaeda of Islam. 1961. London: Luzac.

Mayer, Hans Eberhard. 1988. The Crusades. Oxford: Oxford University Press.

Michel, Thomas. 1981. "Ibn Taymiyya's Sharh on the Futuh al-Ghayb of "Abd al-Qadir al-Jilani" in Hamdard Islamicus, Vol IV No. 2, Summer.

Nasr, Sayyed Hossein. 1991. Sufi Essays. Albany: SUNY 
Press.

Rahman, Fazlur. 1979. Islam. Chicago: University of Chicago Press.

Salik, S.A. The Saint of Jilan. Ghaus-ul-Azam. Lahore: Ashraf Publication.

Schimmel, Annemarie. 1975. Mystical Dimensions of Islam. Chapel Hill: The University of North Carolina Press.

Sell, Canon. 1976. The Religious Orders of Islam. Wilmington: Scholarly Resources, Inc.

Sharif, Mian Mohammad. 1963. A History of Muslim Philosophy, Volume 3. Wiesbaden: Harrassowitz.

Trimingham, J. Spencer. 1971. The Sufi Orders in Islam. Oxford: Oxford University Press.

Watt, W. Montgomery. 1971. Muslim Intellectual. A Study of al-Ghazali. Edinburgh: Edinburgh University Press. 1961. Islam and the Integration of Society. London: Routledge and Kegan Paul. 